\title{
Appraisal of Sulphur Contaminants from Transportation in Urban Zaria, Nigeria
}

\author{
${ }^{1}$ Aliyu, Y. A. \\ ${ }^{2}$ Musa, I. J \\ ${ }^{3}$ Youngu, T. T. \\ ${ }^{1,3}$ Department of Geomatics, Faculty of Environmental Design, \\ Ahmadu Bello University, Zaria-Nigeria \\ ${ }^{2}$ Department of Geography, Faculty of Science, \\ Ahmadu Bello University, Zaria-Nigeria
}

\section{Doi:10.5901/ ajis.2013.v2n10p155}

\section{Abstract}

As a step towards remediation of sulphur contaminants, this study used a Crowcon Gasman (gas detection instrument) to collect and analyze Sulphuric gas samples from densely populated areas of urban Zaria. The results showed varying concentrations of Sulphur Dioxide $\left(\mathrm{SO}_{2}\right)$ and Hydrogen Sulphide $\left(\mathrm{H}_{2} \mathrm{~S}\right)$. The high concentrations of these pollutants detected can be attributed to increased population growth, increased production of gaseous wastes and increased number of vehicular movement. The results indicate also that the concentrations of pollutant sulphur component $\mathrm{SO}_{2}$ measured at all sampling points, with exception of the control site were hazardous while that of $\mathrm{H}_{2} \mathrm{~S}$ were within safe limit set by FEPA and ACGIH respectively. Statistical tests were performed which established significant variation/relationship between detected pollutants and traffic volume. Findings from this study imply that vehicular emission within urban Zaria is not within the safe limit which further reveals that transport-related pollution in Zaria urban area can be potentially hazardous to health.

Keywords: Sulphur, Ambient Air, Health Hazard, Vehicle Emission and Pollution, Environment

\section{Introduction}

Clean air is one of the basic requirements of human existence. However, air pollution continues to pose significant threats to human and environmental health worldwide. According to the World Health Organization (WHO), more than two million premature deaths each year can be attributed to the effects of urban outdoor and indoor air pollution and these effects are more prominent in developing countries (WHO, 2005a). Outdoor air pollution sometimes called ambient air pollution occurs in both rural and urban areas. However, the intensity and type of pollution depends on the available pollution sources.

Sulphur oxides and hydrogen sulphide are two major sulphur-containing air pollutants. Both cause great environmental concern. Most sulphur oxides are released in the form of sulphur dioxide, which reacts in the atmosphere to form sulphates. Findings have shown that these gases interfere with normal breathing patterns, reduce visibility, and contribute to the formation of acid rain (Wang et al., 2005).

Sulphur is a naturally occurring part of crude oil and must be removed during the refining process. Despite this removal, some sulphur remains in finished products, including both gasoline and diesel fuel. When these fuels are burnt, Sulphur Dioxide $\left(\mathrm{SO}_{2}\right)$ and sulphate particulate matter 
are emitted. Reduction in the sulphur content of transport fuels will immediately reduce the emissions of these sulphur pollutants (ACFA, 2008).

Sulphur Dioxide is a colorless gas formed primarily during the combustion of a sulphurcontaining fuel or sulphur-containing industrial waste gases. Once released to the atmosphere, sulphur dioxide reacts slowly because of photo-chemically initiated reactions and reactions with cloud and fog droplets, at rates of between approximately 0.1 percent and 3 percent per hour. These atmospheric reactions yield sulphuric acid, inorganic sulphate compounds, and organic sulphate compounds (Richards, 2000).

Hydrogen Sulphide $\left(\mathrm{H}_{2} \mathrm{~S}\right)$ is emitted from a number of metallurgical, petroleum, and petrochemical processes. Fugitive emission of Hydrogen Sulphide can occur from sour gas wells and certain petrochemical processes. It is a highly toxic gas due to its chemical asphixant characteristics. Despite its strong rotten egg odour, it is often difficult to detect at high concentrations due to rapid olfactory fatigue. Hydrogen Sulphide is highly soluble in water and can be easily oxidized to form sulphur dioxide (Richards, 2000).

The monitoring of air pollutants such as $\mathrm{SO}_{2}$ and $\mathrm{H}_{2} \mathrm{~S}$ in ambient air has received substantial attention over the past several years because they are among the major pollutants which significantly affect the chemistry of the atmosphere and human health (Wu et al., 2003). A recent study by WHO concluded that, "One of the trends predicted to lead to increasing air pollution levels is the high rate of urbanization in countries where most of the population is on low income. It is expected that the rapid growth in urban populations will lead to a dramatic increase in vehicle numbers combined with inexpensive solutions for daily commuting, more frequent use of older and two-wheeled vehicles, poor car maintenance and other developments that increase air pollution" (WHO, 2005b).

Sulphur emissions influence the level of acidification of soils and freshwater ecosystems (Stoddard et al., 1999; Schopp et al., 2003), climate change (Haywood and Boucher, 2000; Ramanathan et al., 2001) and have impacts on human health (WHO, 2003; 2005b; 2006). The acidification situation was serious in large parts of northern Europe in the 1970s, mainly in the Fenno-Scandia region also due to slow weathering of soil and bedrock. Significant exceedances of critical loads were observed over large parts of central Europe, southern parts of Scandinavia and North-Western Europe (Lovblad et al., 2004). Emission and successive deposition of sulphur have caused material, soil and forest damage (Nellemann and Goul Thomsen, 2001; Akselsson et al., 2004) and surface water acidification.

WHO (2000) also reported that in dry unpolluted atmospheric conditions, it is estimated that the average $\mathrm{SO}_{2}$ concentration for urban areas showed annual mean ranging from 20 to $60 \mu \mathrm{g} / \mathrm{m}^{3}$ ( 0.0072 to $0.022 \mathrm{ppm})$ and daily means rarely exceeding $125 \mu \mathrm{g} / \mathrm{m}^{3}(0.045 \mathrm{ppm})$.

Riordan and Adeeb (2004) carried a study on $\mathrm{SO}_{2}$ concentration level in four sample points (Christies Beach, Elizabeth, Northfield and Kensington) all within Adelaide metropolis. Their findings show that $\mathrm{SO}_{2}$ concentration level did not exceed the $0.08 \mathrm{ppm}$ one-day standard stipulated by the National Environment Protection Measure (NEPM). Therefore, the concentration level is not likely to have an adverse impact on either human health or vegetation in the metropolitan Adelaide region.

Barman et al., (2008) conducted a study on the ambient air quality of the city Lucknow, India during Diwali festival. Results showed varied concentrations of $\mathrm{PM}_{10}, \mathrm{SO}_{2}$ and $\mathrm{NO}_{\mathrm{x}}$ for observations taken at four representative locations, during day and night times for Pre Diwali (day before Diwali) and Diwali day. On Diwali day, 24-hour average concentration of $\mathrm{SO}_{2}$ was found to be $139.1 \mu \mathrm{g} / \mathrm{m}^{3}$ $(0.05 \mathrm{ppm})$ and this concentration was found to be higher at 1.95 and 6.59 times higher when compared with the respective concentration of Pre Diwali and normal day. On Diwali night (12hour) mean level of $\mathrm{SO}_{2}$ was $205.4 \mu \mathrm{g} / \mathrm{m}^{3}(0.074 \mathrm{ppm})$ which was 2.82 times higher than the daytime concentration.

This study intends to appraise the level of sulphur contaminants from transportation in urban Zaria as a result of tremendous increase in urbanization and vehicular ownership. 


\section{The Study Area}

Zaria urban area is located in the central plains of the northern Nigeria highlands standing at an average height of $670 \mathrm{~m}$ above mean sea level. It is the second largest city in Kaduna State with a geographical position located between East longitudes $7^{\circ} 36^{\prime} 00^{\prime \prime}-7^{\circ} 46^{\prime} 00^{\prime \prime}$ and North latitudes $11^{\circ} 02^{\prime} 00^{\prime \prime}-11^{\circ} 12^{\prime} 00^{\prime \prime}$. It comprises of parts of Zaria and Sabon-Gari Local Government Areas transversing about $70 \mathrm{~km}$ from the west to east and roughly cover 8,950 square kilometers. It is drained by three major rivers namely: River Kubanni, River Saye and River Galma. The climatic characteristic is that of tropical savanna (Mortimore, 1970). According to the National Population Commission, the population of Zaria and Sabon Gari Local Government Area were totaled to be 695,069 people (NPC, 2006).

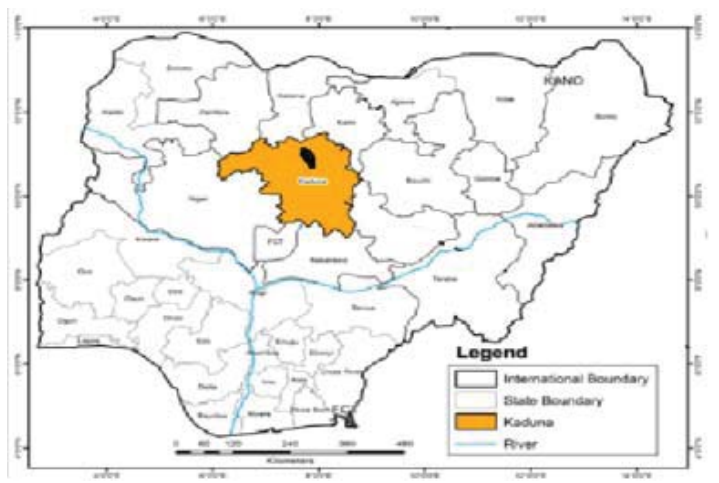

Figure 1: Map of Nigeria showing Kaduna State and Urban Zaria

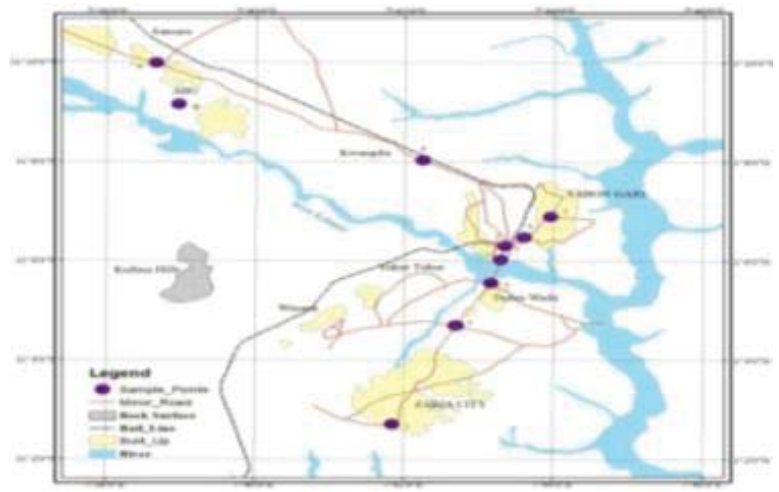

Figure 2: Distribution of sampling points (Topographical Map of Zaria, Sheet 102)

\section{Materials and Methods}

This study is an exposure assessment performed in Zaria urban area in the northern part of Kaduna state, Nigeria. After reviewing the map of the study area, ten (10) sampling points were selected (See Figure 2). These include: the Zaria city market, Kofar Doka roundabout (R/A), Tudun Wada Agwaro roundabout (R/A), Park road roundabout (R/A), Kalabari off Aminu road junction and Total filling station junction both in Sabon Gari, PZ Samaru Bus stop, Kwangila Bridge, Samaru market and Ahmadu Bello University Staff School which serves as a control point. A total of 210 samples 
were obtained from the selected areas during morning, afternoon and evening observation periods with 21 samples collected from each sampling point.

Traffic count was conducted to obtain statistics of car/motorcycle/truck movement in the various sampling traffic points. Concentration level of $\mathrm{SO}_{2}$ and $\mathrm{H}_{2} \mathrm{~S}$ were measured using the Crowcon Gasman sensor. The Crowcon (Gasman) gas sensor which was rented from the Kaduna State Enviromental Protection Agency (KEPA) is a unique single-gas monitor for detection of flammable gases, oxygen and toxic gases. It offers flexibility, assurance, and robustness. Intrinsically safe, it is a portable gas detector with embedded software designed to the exacting requirements of International Electrotechnical Commission (IEC 61508-3) which is the international standard for electrical, electronic and programmable electronic safety related systems, guaranteeing reliable and dependable operation. It was used in this study to record emission values of hazardous gases detectable at these traffic points.

Concentration level of these pollutant gases was obtained for a 7-day period at various sampling points along major motor roads within commercial areas in urban Zaria at different times so that the survey is statistically representative of the existing conditions of the concentration level. These times were: 7:30 - 9:15am, 12:30 - 2:15pm and 4:30 - 6:15pm. Measurements were performed when wind was near static and temperature was averagely about $29.8,40.3$ and $30.9^{\circ} \mathrm{C}$ for morning, afternoon and evening sampling periods respectively. The raw data obtained from this study were analyzed using statistical methods. The sampling points over which measurements were done are as shown in Fig. 1 above and obtained $\mathrm{SO}_{2}$ concentration level was compared with the Federal Environmental Protection Agency (FEPA) standard limit of 0.01- 0.1ppm (FEPA, 1991),

\section{Results and Discussion}

Results obtained for the volume and composition of vehicular movements within the various sampling points indicated in Figure 2, Figure 3. It showed that the volume of motorcycles is more than that of motors and trucks. Kwangila bridge sample point is a major junction which links Zaria City-Sabon Gari-Samaru and to other states like Katsina, Kano, Sokoto, Zamfara and Kebbi. While Kalabari off Aminu road junction sample point in Sabon Gari (which is the centre of commercial activity) has the highest number of motorcycles. This can be attributed to the fact that the Sabon Gari market is very close to the sampling point.

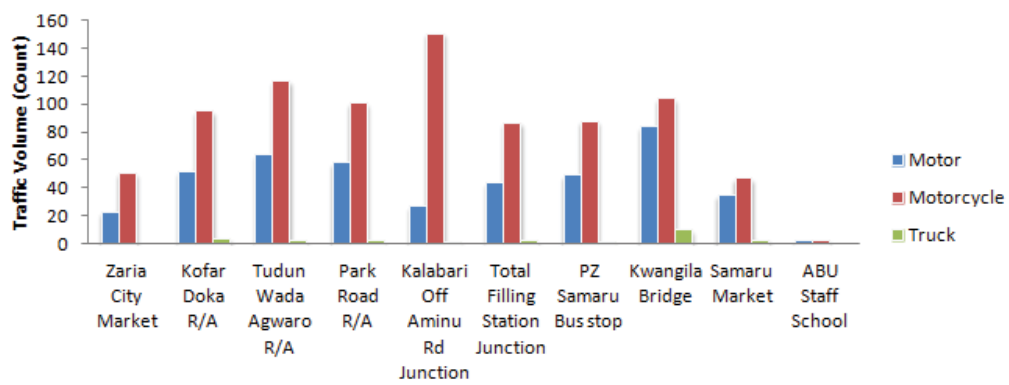

Figure 3: Average traffic volume across various sampling points

The concentration of Sulphur Dioxide $\left(\mathrm{SO}_{2}\right)$ ranged from $0.059-0.081 \mathrm{ppm}$ for Zaria City market sample point; $0.069-0.084$ ppm for Kofar Doka Roundabout; $0.078-0.086$ ppm for Tudun Wada Agwaro Roundabout; 0.069 - $0.081 \mathrm{ppm}$ for Park Road Roundabout; $0.068-0.081 \mathrm{ppm}$ for Kalabari off Aminu Road Junction; $0.073-0.087 \mathrm{ppm}$ for Total filling station Junction; 0.069 $0.088 \mathrm{ppm}$ for PZ Samaru Bus stop; $0.073-0.083$ ppm for Kwangila under bridge; $0.057-0.075$ ppm for Samaru market and $0.021-0.027$ ppm for ABU Staff School which serves as the control point. 
Table 1 and Figure 4 show the variation across sampling days and sampling periods respectively.

Table 1: Average Sulphur Dioxide $\left(\mathrm{SO}_{2}\right)$ Emission across sampling sites

\begin{tabular}{lccccccc}
\hline & Mon & Tue & Wed & Thurs & Fri & Sat & Sun \\
Zaria City Market & 0.081 & 0.071 & 0.073 & 0.072 & 0.074 & 0.059 & 0.069 \\
Kofar Doka R/ A & 0.077 & 0.079 & 0.084 & 0.077 & 0.08 & 0.069 & 0.076 \\
Tudun Wada Agwaro R/ A & 0.081 & 0.08 & 0.086 & 0.078 & 0.085 & 0.08 & 0.082 \\
Park Road R/ A & 0.078 & 0.081 & 0.079 & 0.073 & 0.083 & 0.079 & 0.069 \\
Kalabari Off Aminu Rd J unction & 0.081 & 0.077 & 0.081 & 0.073 & 0.078 & 0.081 & 0.068 \\
Total Filling Station J unction & 0.084 & 0.078 & 0.085 & 0.073 & 0.087 & 0.079 & 0.074 \\
PZ Samaru Bus stop & 0.078 & 0.081 & 0.088 & 0.079 & 0.083 & 0.081 & 0.069 \\
Kwangila Bridge & 0.08 & 0.083 & 0.081 & 0.078 & 0.077 & 0.079 & 0.073 \\
Samaru Market & 0.075 & 0.073 & 0.072 & 0.062 & 0.073 & 0.065 & 0.057 \\
ABU Staff School & 0.022 & 0.026 & 0.02 & 0.027 & 0.023 & 0.021 & 0.027 \\
\hline
\end{tabular}

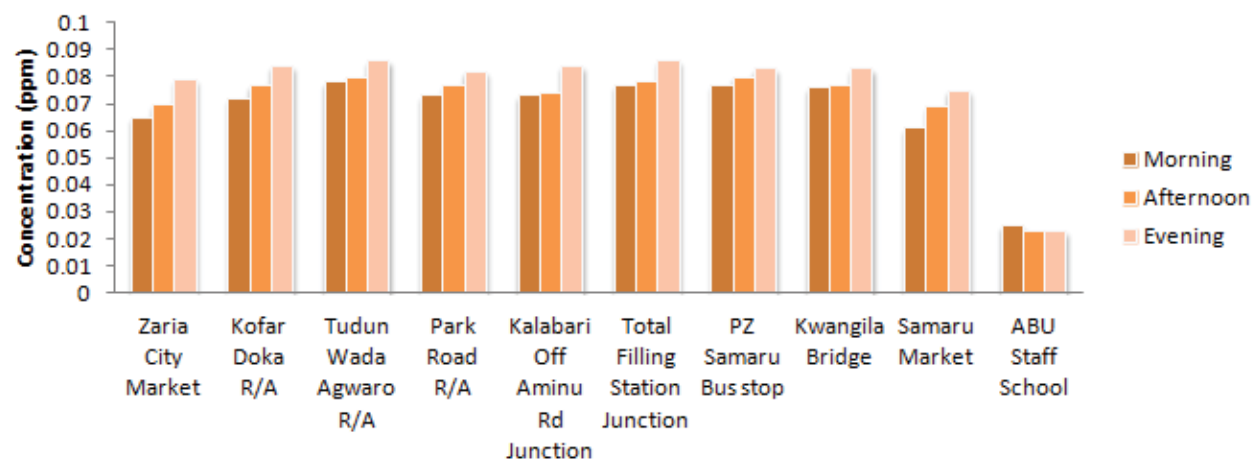

Figure 4: Mean Variation of Sulphur Dioxide $\left(\mathrm{SO}_{2}\right)$ across periods at sampling points

For Hydrogen Sulphide $\left(\mathrm{H}_{2} \mathrm{~S}\right)$, as stated in Table 2, the concentration level ranged from $0.42-0.66$ ppm for Zaria City market; $0.50-0.69$ ppm for Kofar Doka Roundabout; $0.60-0.73$ ppm for Tudun Wada Agwaro Roundabout; $0.54-0.67$ ppm for Park Road Roundabout; 0.55 - 0.69 ppm for Kalabari off Aminu Road Junction; $0.58-0.69 \mathrm{ppm}$ for Total filling station Junction; $0.55-0.75$ ppm for PZ Samaru Bus stop; $0.53-0.74$ ppm for Kwangila under bridge; $0.43-0.64$ ppm for Samaru market and $0.18-0.26 \mathrm{ppm}$ for ABU Staff School which serves as the control point. Variation of $\mathrm{H}_{2} \mathrm{~S}$ along the various sampling points is further displayed in Figure 5

Table 2: Average Hydrogen Sulphide $\left(\mathrm{H}_{2} \mathrm{~S}\right)$ Emission across sampling sites

\begin{tabular}{lccccccc}
\hline & Mon & Tue & Wed & Thurs & Fri & Sat & Sun \\
Zaria City Market & 0.61 & 0.66 & 0.63 & 0.63 & 0.64 & 0.42 & 0.63 \\
Kofar Doka R/ A & 0.56 & 0.7 & 0.65 & 0.64 & 0.71 & 0.5 & 0.69 \\
Tudun Wada Agwaro R/ A & 0.62 & 0.73 & 0.7 & 0.61 & 0.72 & 0.6 & 0.69 \\
Park Road R/ A & 0.62 & 0.71 & 0.67 & 0.55 & 0.69 & 0.54 & 0.6 \\
Kalabari Off Aminu Rd J unction & 0.66 & 0.66 & 0.68 & 0.69 & 0.64 & 0.55 & 0.58 \\
Total Filling Station J unction & 0.64 & 0.69 & 0.67 & 0.69 & 0.68 & 0.58 & 0.69 \\
PZ Samaru Bus stop & 0.64 & 0.73 & 0.75 & 0.76 & 0.71 & 0.55 & 0.56 \\
Kwangila Bridge & 0.6 & 0.74 & 0.68 & 0.73 & 0.67 & 0.53 & 0.63 \\
$\quad$ Samaru Market & 0.62 & 0.64 & 0.63 & 0.46 & 0.61 & 0.43 & 0.49 \\
\multicolumn{1}{c}{ ABU Staff School } & 0.18 & 0.26 & 0.2 & 0.21 & 0.19 & 0.21 & 0.23 \\
\hline
\end{tabular}




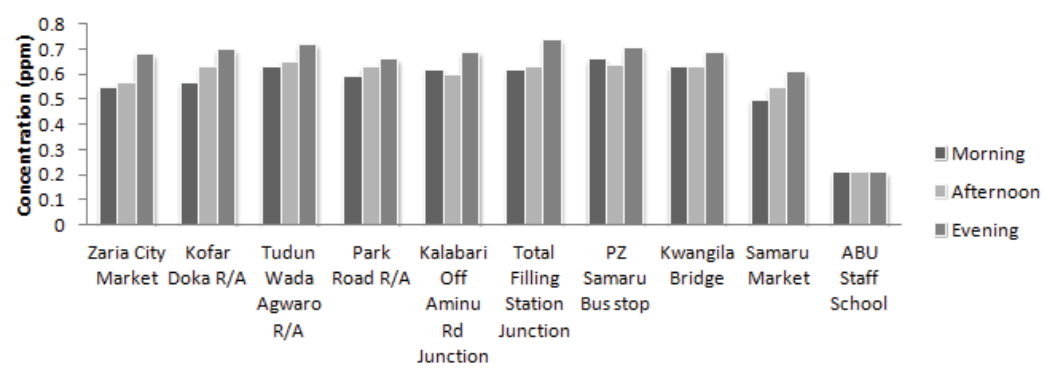

Fig. 5: Mean Variation of Hydrogen Sulphide $\left(\mathrm{H}_{2} \mathrm{~S}\right)$ across periods at sampling points

From Figures 4 and 5, there is clear indication that on the average, evening periods recorded the highest level of $\mathrm{SO}_{2}$ concentration. This can be attributed to flexibilty of the morning traffic whereby commuters/vehicle owners move at varying time-frames from as early as 6.30am for the primary/secondary student and working class and as late as 9.30am for the business operators/marketers. While for the evening traffic hours, the same workers who leave home as early as 7am do not have the laxity of closing work earlier than $3.45 \mathrm{pm}$. This coincides with secondary school students extra moral lesson closing rush and market closing rush all on a limited access route. These is in agreement to the findings of high evening and lower morning periods of pollutant gases concentration as reported by Ragini et al. (2009); Okunola et al. (2012) where concentration of pollutant gases was lowest in the morning period.

However taking one of the sampling points into consideration (Kwangila which records most of the high concentration levels) it can be seen in Figures 6 and 7 below that not all evening periods record higher concentration levels of $\mathrm{SO}_{2}$ across the sampling days. While other days had higher evening concentration levels, Friday had a higher concentration during the afternoon period. This can be attributed to the fact that the sampling point (Kwangila) serves as a transit route for travellers going to other north-western states which run into the evening hours. Also Saturday morning period had the highest concentration for the day. This also can be attributed to the continuous travelling activities at the Kwangila bridge sampling point while the close gap for afternoon and evening periods can be attributed to the fact that most wedding events occur on that day.

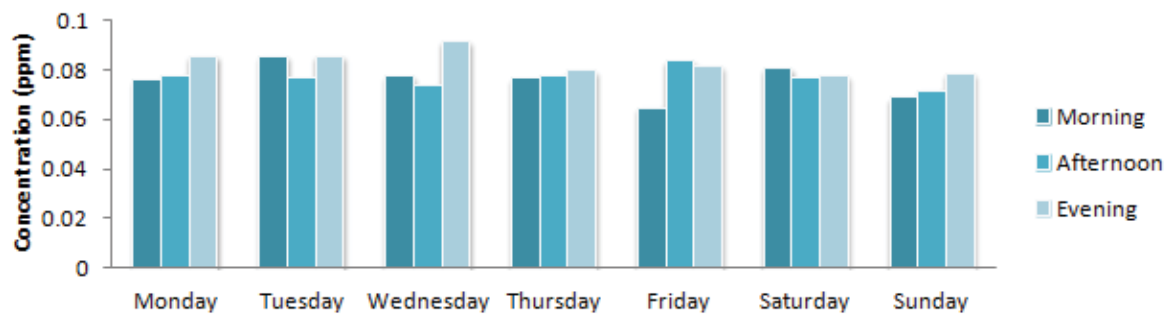

Fig. 6: Variation of Sulphur Dioxide $\left(\mathrm{SO}_{2}\right)$ across periods at sampling days for Kwangila

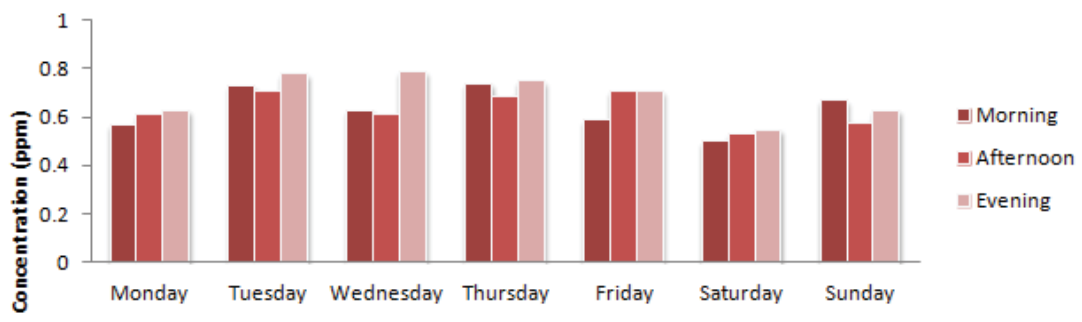

Fig. 7: Variation of Hydrogen Sulphide $\left(\mathrm{H}_{2} \mathrm{~S}\right)$ across periods at sampling days for Kwangila 
From the results obtained for $\mathrm{SO}_{2}$ and $\mathrm{H}_{2} \mathrm{~S}$, it can be seen that highest level of $\mathrm{SO}_{2}$ was recorded still at the Tudun Wada sampling point. Positive significant correlation at 0.01 and 0.05 levels (Table 5 below) between $\mathrm{SO}_{2}$ and Motorcycles/cars during this season could be responsible. Furthermore, the concentration of $\mathrm{SO}_{2}$ is lower than ranges of $3.21-5.18 \mathrm{ppm}, 7.4-15.5 \mathrm{ppm}$, and 16 - 64 ppm reported by Ayodele and Abubakar (2010), Ettouney et al. (2010), and Kalabokas et al. (1999), respectively but was with the range of $0.03-0.09 \mathrm{ppm}$ reported in Kano metropolis, Nigeria (Okunola et al., 2012). The reasons for these values at these points may be attributed to several processes such as, refuse dumpsite located along these sites. Comparing data with the FEPA standard level of $0.06 \mathrm{ppm}$, the air quality for $\mathrm{SO}_{2}$ ranged between moderate and poor (between the stipulated $0.01-0.1$ ) in most of the sampling sites while at the ABU Staff School which is the control site, $\mathrm{AQI}$ for $\mathrm{SO}_{2}$ was good.

For $\mathrm{H}_{2} \mathrm{~S}$, the ambient area quality is acceptable for all the sites. This is because even though (WHO, 1981) stated that "there is no international standards for $\mathrm{H}_{2} \mathrm{~S}$, many countries have adopted 'short time' standards". Since FEPA has no quality standard for $\mathrm{H}_{2} \mathrm{~S}$, this study is compelled to compare with an international standard. ACGIH, (2005) announced their intention to lower the time-weighted-average (TWA) work-day limit from $10 \mathrm{ppm}$ to $1 \mathrm{ppm}$ and for short-term (15 minutes) exposure limit from $15 \mathrm{ppm}$ to $5 \mathrm{ppm}$. From this it can be said that, even with a dump site close to some of the sampling points, the concentration level of $\mathrm{H}_{2} \mathrm{~S}$ is still within safe limits.

Tables 3 and 4 present summary of statistical analyses (ANOVA and Pearson's correlation) that was conducted to determine if there was any variation/relationship between detected pollutant gases $\mathrm{SO}_{2}$ and $\mathrm{H}_{2} \mathrm{~S}$ with traffic volume at $\mathrm{p}=0.05$ significant level.

Table 3: Analysis of Variance (ANOVA)

\begin{tabular}{|c|c|c|c|c|c|c|}
\hline & & Sum of Squares & df & Mean Square & $\mathbf{F}$ & Sig. \\
\hline \multirow{3}{*}{$\mathrm{SO}_{2}$} & \multirow{3}{*}{$\begin{array}{l}\text { Between Groups } \\
\text { Within Groups } \\
\text { Total }\end{array}$} & \begin{tabular}{|l|}
.057 \\
\end{tabular} & 9 & .006 & 90.553 & .000 \\
\hline & & .014 & 200 & .000 & & \\
\hline & & .070 & 209 & & & \\
\hline \multirow{3}{*}{$\mathrm{H}_{2} \mathrm{~S}$} & \multirow{3}{*}{$\begin{array}{l}\text { Between Groups } \\
\text { Within Groups } \\
\text { Total }\end{array}$} & 3.639 & 9 & .404 & 48.834 & .000 \\
\hline & & 1.656 & 200 & .008 & & \\
\hline & & 5.295 & 209 & & & \\
\hline \multirow{3}{*}{ Cars } & \multirow{3}{*}{$\begin{array}{l}\text { Between Groups } \\
\text { Within Groups } \\
\text { Total }\end{array}$} & 101621.981 & 9 & 11291.331 & 36.334 & .000 \\
\hline & & 62153.714 & 200 & 310.769 & & \\
\hline & & 163775.695 & 209 & & & \\
\hline \multirow{3}{*}{ Motorcycles } & \multirow{3}{*}{$\begin{array}{l}\text { Between Groups } \\
\text { Within Groups } \\
\text { Total }\end{array}$} & 322928.671 & 9 & 35880.963 & 28.316 & .000 \\
\hline & & 253431.810 & 200 & 1267.159 & & \\
\hline & & 576360.481 & 209 & & & \\
\hline \multirow{3}{*}{ Trucks } & \multirow{3}{*}{\begin{tabular}{|l|} 
Between Groups \\
Within Groups \\
Total
\end{tabular}} & 1515.448 & 9 & 168.383 & 13.970 & .000 \\
\hline & & 2410.667 & 200 & 12.053 & & \\
\hline & & 3926.114 & 209 & & & \\
\hline
\end{tabular}

Table 4: Correlation between detected $\mathrm{SO}_{2}$ and $\mathrm{H}_{2} \mathrm{~S}$ with traffic volume

\begin{tabular}{cccccc}
\hline & $\mathbf{S O}_{2}$ & $\mathbf{H}_{2} \mathbf{S}$ & Cars & Motorcycles & Trucks \\
$\mathbf{S O}_{2}$ & 1 & $0.998^{* *}$ & $0.718^{*}$ & $0.791^{* *}$ & 0.344 \\
$\mathbf{H}_{2} \mathbf{S}$ & $0.998^{* *}$ & 1 & $0.700^{*}$ & $0.792^{* *}$ & 0.319 \\
Cars & $0.718^{*}$ & $0.700^{*}$ & 1 & 0.585 & $0.758^{*}$ \\
Motorcycles & $0.791^{* *}$ & $0.792^{* *}$ & 0.585 & 1 & 0.297 \\
Trucks & 0.344 & 0.319 & $0.758^{*}$ & 0.297 & 1 \\
\hline
\end{tabular}

$* *$. Correlation is significant at the 0.01 level (2-tailed)

$*$. Correlation is significant at the 0.05 level (2-tailed) 
Table 3 confirmed that there is significant variation between grouped as determined by one-way ANOVA $(\mathrm{F}(9,200)=90.553 ; 48.834 ; 36.334 ; 28.216 ; 13.970)$ for $\mathrm{SO}_{2}, \mathrm{H}_{2} \mathrm{~S}$, Cars, Motorcycles and Trucks respectively.

This result is also subjected to correlation (See Table 4) which indicates a strong significant correlation $(p<0.01)$ between detected sulphur contaminants $\left(\mathrm{SO}_{2}\right.$ and $\left.\mathrm{H}_{2} \mathrm{~S}\right)$ with motorcycles while the correlation with cars is at $p<0.05$ significant level. There was no correlation between the detected pollutant gases with heavy duty vehicles (trucks). This can be attributed to the fact that only three (Kofar-Doka Roundabout, Kwangila bridge and Samaru market) out of the ten sampling points recorded significant number of trucks. But there was correlation $(P<0.05)$ between cars and trucks. This can also be attributed to their orderly movement along access routes unlike motorcycles which move in clusters.

\section{Conclusion}

An analysis of Sulphur Dioxide and Hydrogen Sulphide from vehicular emission in ambient air of urban Zaria showed the presence of the various degrees of these pollutants. Varying concentrations of these gases were detected at all sampling points, with exception of the control site. It is imperative therefore that the expansion of urban Zaria road network, standard control measures and proper waste disposal methods should be quickly put in place to avoid continuous emission that may lead to increased concentration of these pollutants. It is recommended that extensive awareness campaigns be carried out and further study will be appropriate to ascertain and proffer mitigation measures on their effects on humans and the environment.

\section{References}

ACFA, (2008). Sulphur Reduction - The Key to Lower Vehicle Emissions. Asian Clean Fuels Association Monthly Publication Vol. 6, Issue 6 - Aug/Sept, 2008

ACGIH, (2005). Guide to Occupational Exposure Values "Notice of Intended Changes". American Conference of Governmental Industrial Hygienists In: MCDCP, (2006). Ambient Air Guidelines for H2S. Maine Centre for Disease Control and Prevention. Augusta, USA. Retrieved February 2, 2013, from: http://www.maine.gov/dep/waste/publications/documents/ambientairguidelines.pdf

Akselsson, C., Ardo, J., and Sverdrup, H. (2004). Critical Loads of Acidity for Forest Soil and Relationship to Forest Decline in the Northern Czech Republic. Environmental Monitoring and Assessment. 98: 363-379

Barman S.C., Singh R., Negi, M. P. S. and Bhargava, S. K. (2008). Ambient Air Quality of Lucknow City (India) during Use of Fireworks on Diwali Festival, Environ Monit. Asses, No 137: 495-504

Ettouney, R. S., Zaki, J. G., El-Rifiai, M. A. and Ettouney, H. M. (2010), An Assessment of the Air Pollution Data from Two Monitoring Stations in Kuwait, Toxicology and Environmental Chemistry, Vol. 92 No. 4, pp. $655-668$

Federal Environmental Protection Agency, (1991). Guidelines and Standards for Environmental Protection Control in Nigeria. In Ajayi, A. B. and Dosunmu, O. O. (2002). Environmental hazards of Importing Used Vehicles into Nigeria. Proceedings of International Symposium on Environmental Pollution Control and Waste Management (EPCOWM). (7-10) January 2002, Tunis, Tunisia. Pp. 521-532

Haywood, J. and Boucher, O. (2000). Estimates of the Direct and Indirect Radiative Forcing due to Tropospheric Aerosols: A Review. Reviews of Geophysics 38(4): 513-543

Kalabokas, P. O., Viras, L. G. and Repapis, C. (1999), "Analysis of the 11 - years record (1987 - 1997) of Air Pollution Measurements in Athens, Greece, Part I: Primary Air Pollutants", Global Nest Journal, Vol. 1 No. 3, pp. $157-167$

Lovblad, G., Tarrason, L., Tørseth, K., and Dutchak, S. (Eds.) (2004). EMEP Assessment Report Part I, European Perspective, Retrieved July 15, 2013, from: http://www.emep.int

Mortimore, M. J. (ed)(1970). Zaria and its Region: A Nigerian Savanna City and its Environs. Department of Geography, Ahmadu Bello University Zaria. Occasional Paper No 4 
Nellemann, C. and Goul Thomsen, M. (2001). Long-Term Changes in Forest Growth: Potential Effects of Nitrogen Deposition and Acidification. Water, Air, \& Soil Pollution Vol. 128: 197-205

NPC, (2006). Population. National Population Commission Census Report. Nigerian Statistics Annual Report. Pp. 14 Retrieved May 22, 2012, from: http://www.nigerianstat.gov.ng/nbsapps /annual_reports/CHAPTER\%202.pdf/

Okunola, O. J., Uzairu, A., Gimba C. E. and Ndukwe, G. I. (2012). Assessment of Gaseous Pollutant along High Traffic Roads in Kano, Nigeria. International Journal of Environment and Sustainability. Volume 1(1): 1-15

Ragini, N., Chandrashekara, M. S., Nagaiah, N. and Paramesh, L. (2009). Study of Atmospheric Electrical

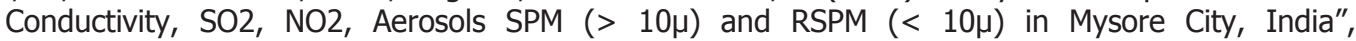
Toxicology and Environmental Chemistry. Vol. 91(4): 605 - 609

Ramanathan, V., Crutzen, P. J., Kiehl, J. K., and Rosenfeld, D. (2001). Aerosols, Climate, and the Hydrological Cycle, Science. 294, 2119-2124

Riordan, D. and Adeeb, F. (2004). Air Quality Monitoring for Sulphur Dioxide in Metropolitan Adelaide. Environment Protection Authority Document. Retrieved July 3, 2013 from: http://www.epa.sa .gov.au /xstd_files/Air/Report/so2_report.pdf

Richards, J. K. (2000). Control of Gaseous Emissions. United States Environmental Protection Agency Air Pollution Training Institute (USEPA APTI). Student Manual Course 415. Third Edition. Retrieved July 1, 2013, from: http://www.4cleanair.org/apti/415combined.pdf

Schopp, W., Posch, M., Mylona, S., and Johansson, M. (2003). Long-Term Development of Acid Deposition (1880-2030) in Sensitive Freshwater Regions in Europe. Hydrology and Earth System Sciences (7): 436-446

Stoddard, J. L., Jeffries, D. S., Lukewille, A., Clair, T. A., Dillon, P. J., Driscoll, C. T., Forsius, M., Johannessen, M., Kahl, J. S., Kellogg, J. H., Kemp, A., Mannio, J., Monteith, D. T., Murdoch, P. S., Patrick, S., Rebsdorf, A., Skjelkvale, B. L., Stainton, M. P., Traaen, T., van Dam, H., Webster, K. E., Wieting, J., and Wilander, A. (1999). Regional Trends in Aquatic Recovery from Acidification in North America and Europe. Nature. 401(6753): 575-578

Wang, L. K., Pereira, N. C. and Hung, Y. T. (2005). Advanced Air and Noise Pollution Control. Hand book of Environmental Engineering, Volume 2. Humana Press Inc. Totowa, NJ.

WHO, (1981). Hydrogen Sulphide. World Health Organization, Environmental Health Criteria No. 19. Geneva.

WHO, (2000). Air Quality Guidelines for Europe, Second Edition. WHO Regional Publications, European Series No. 91,Regional Office for Europe, Copenhagen. In Blair, L. (2003). Sulphur Dioxide: Environmental Effects, Fate and Behaviour. Alberta Environment. Retrieved July 4, 2013, from: http://environment.gov.ab.ca/info/library/6615.pdf

WHO, (2003). Health Aspects of Air Pollution with Particulate Matter, Ozone and Nitrogen dioxide, Report on a WHO Working Group, Copenhagen, WHO Regional Office for Europe (document EUR/03/5042688), available from http://www.euro.who. int/document/e79097.pdf

WHO, (2005a). WHO Air Quality Guidelines Global Update. Report on a Working Group Meeting, Bonn, Germany, 18-20 October 2005, WHOLIS number E87950

WHO, (2005b). Hydrogen Sulphide. Geneva World Health Organization, Environmental Health Criteria, No. 19.

WHO, (2006). Health Risks of Particulate Matter from Long-Range Transboundary Air Pollution. Joint WHO/Convention Task Force on the Health Aspects of Air Pollution, WHO Regional Office for Europe, European Centre for Environment and Health, Bonn Office, WHOLIS number E88189

Wu, C., Lin, M., Feng, C., Yang, K., Lo, Y. and Lo, J. (2003). Measurement of Toxic Volatile Organic Compounds in Indoor Air of Semiconductor Foundries Using Multi-sorbent Adsorption/ Thermal Desorption coupled with Gas Chromatography-Mass Spectrometry. Journal of Chromatography Vol. 996: 225-231 
